\title{
Assessment of initial stock of Levisticum officinalis C. Koch and Leonurus guinguelobatus Gilib on complex of attributes
}

\section{Kormosh S.}

Zakarpattian state agricultural experimental station, Svobody avenue, 17, V. Bakta, Beregovskyi region, Zakarpattia oblast, 90252, Ukraine; e-mail: insbakta@ukr.net

The purpose. To study influence of climatic conditions on growth, development and formation of productivity of Levisticum officinalis $\mathrm{C}$. Koch and Leonurus guinguelobatus Gilib, as well as to determine adaptable potential of samples of initial stock. Methods. General scientific and special: field - for determination of differences in alternatives of research; laboratory - for determination of biochemical compound of raw material; gene-tic for determination of parameters of combining ability; mathematical-statistical - for assessment of reliability of the gained results. Results. As to economic-valuable attributes of MLL and Koral they selected samples of lovage. Grades of foreign selection Lovage and Redei have appeared resistant against conditions of growing in low zone of Zakarpattia. Samples of motherwort are revealed which can be sources of the following valuable attributes: short term of vegetation (Krasunia, CRBS), height of a bush (SK-2, Zabava, CRSB), diameter of a bush (Krasunia, Zabava, SK-1), content of useful matters (Zabava, SK-2, Krasunia), amount of caulises (SK-1, SK-2), branches of the 1st and 2nd orders (Zabava, SK-2) and racemes (SK-1, SK-2) on a bush. Investigation in adaptibility of lovage and motherwort plants confirms genotypic variability of formation of productivity and influence of clima-tic conditions on these processes. Conclusions. Studying gene pool of Levisticum officinalis C. Koch and Leonurus guinguelobatus Gilib in conditions of Zakarpattia has shown that these crops are perspective for growing in conditions of low zone.

Key words: assessment, initial stock, lovage, motherwort, adaptibility, productivity, grades, productivity.

https://doi.org/10.31073/agrovisnyk201902-05

Introduction. Levisticum officinalis C. Koch i Leonurus guinguelobatus Gilib - are valuable food and technical plants which possess the healing qualities. These cultures are economically profitable for growing and their raw material is being used in the food, pharmacological, canning and other branches of production which are being developed in a fast rate in the Carpathian region. We should mention that the value of the medicinal lovage and motherwort five lobed for Transcarpathia lies as well in the fact that they are undemanding to the conditions of growing and can grow on the low humus sour, hard and poor soils unfavorable for growing other valuable agricultural crops. [1]. Low level of provision with the productive soils in the region, development of the canning and recycling branch with the various aromatic additives, presence of the healing- health improving institutions, health resorts, sanatoriums with the thermal springs, development of the green tourism and decorative horticulture opens the new spheres of the use of these cultures and the new markets of raw materials' sales. [2, 3].

The raw material of the medicinal lovage is the whole plant. For the food and pharmaceutical production juvenile rosette shaped leaves which had been collected before blooming in the fresh and dry form, as well as the roots, which are stored from the second year of growing, are used. For the technical aims the whole plant is used, which contains a considerable amount of biologically active sources and essential oils (in the leaves the part of the essential oil makes up to $0,25 \%$, in the roots - to $0,5 \%$, in the fruits $-1,5 \%$ on the raw mass) [4].

Motherwort five-lobed raw materials (juvenile blooming shoots collected during the phase of early blossoming) are used in the pharmaceutical branch for the production of various preparations and herbal mixes. [5].

Modern market conditions put forward new requirements for the use in production of the varieties with a high adaptive potential that can provide high yields and quality of raw materials under significant changes in climatic conditions. For the manufacturer it is valuable for the plants to have a high yield of raw material. It is possible to meet the needs of the producer and consumer with the high-quality raw materials, introducing into 
production of the competitive varieties with high content of biologically active substances suitable for mechanized harvesting, resistant to harmful organisms and adapted to the soil - climatic conditions.

This can be achieved by creating some early varieties that could give two or three slopes during vegetation. However the characteristics of early ripening can be achieved not only by reducing the vegetation in general, but also by reducing the duration of individual phases of plant development and deeper study of characteristics of growth and development of plants and influence of agro-climatic conditions on these processes. However, the difficulties that arise in solving the problem of lovage and motherwort are the lack of a wide variety of high-quality staff, information on the degree of variability of the valuable selection features (depending on growing conditions) and formation performance with a high content of bioactive substances. So, there is a question and a task before the scientists to create the initial and selection materials and subsequently the varieties with a high potential for adaptability and productivity of the commodity raw materials [6,7], on which our investigations had been aimed.

The important characteristics of the genetic value of the initial forms is the adaptive potential as the unstable ability of the genotype to resist the negative influence of the factors of environment and the formation of the high productivity and yield capacity of plants. We should mention that defying the parameters of changeability of the variety characteristics and their influence on receiving the highly productive qualitative raw material hasn't yet received the corresponding extension [8], and especially it concerns the aromatic medicinal plants - lovage and motherwort. It is extremely necessary to find a scientifically grounded approach in creating the source material, which would involve into the selection process, harmoniously combine the amount of crops, commodity quality of raw materials, optimal biochemical parameters and technological properties. Successful resolution of the selection problem to a high productivity and quality significantly depends on the knowledge of the deep analysis of the genotype and phenotype on the productivity of plants in the given ecological conditions and the response of plants to the sharp changes in climatic conditions that has been taken place in recent years. [9-10].

In order to realize the potential of plant productivity of lovage and motherwort, it's necessary to identify the maximum of optimal signs of productivity and adaptability. It should be noted that the crop yield and plant adaptability are the complex characteristics. Therefore, it is important to study the relationship between the components of these characteristics, the structure of the phenotype and its components, the formation of quantitative and qualitative characteristics, depending on the conditions of cultivation, to evaluate and identify valuable samples for the further stages of the selection process. These important issues are topical, both for Ukraine as a whole and for Transcarpathia in particular, especially for the low spread, but perspective for the region, plants.

Aim of investigations. To investigate the influence of the climate conditions on the growth, development of plants and forming of the commodity raw materials of the following plants - Levisticum officinalis C. Koch. and Leonurus guinguelobatus Gilib and to study the adaptive potential of the parent material' samples.

Methods of investigations. Scientific researches were conducted on the fields of Zakarpatian State agricultural experimental station (2011-2016 years) on the soddy podzolic gleyed soils. Surface soil, which had been characterized during the years of investigations by the low content of humus $-1,9-2,1 \%$, nitrogen, which is easily hydrolyzed $-9,6-10,4 \mathrm{mg}$, moving phosphorus - 6,9-7,2 and changeable potassium-12,3-12,9 mg per $100 \mathrm{~g}$ of soils, $\mathrm{pH}$ salt $-5,5-5,6$.

In the seedling of the parental material, seven samples of the medicinal lovage were studied (two varieties of foreign selection and two - of the home selection, forms of local populations), five specimens of motherwort five lobed (local forms, standard sort Zabava and newly created variety Krasunya, which were presented in the State variety tests), assessment of the collection samples according to the growth and development of plants, the duration of the vegetative period of plants, depending on the extreme conditions of cultivation, productivity and the yield of biologically active substances had been made.

The investigations and the analysis of the results had been made according to the methodical instructions [11-13], the description of the plants of this type had been made according with the classifiers worked out by the author [14-15]. The assessment of the adaptivity, flexibility, stability and selective value of 
genotypes of the samples of lovage and motherwort had been made under A.V. Kilchevskiy and L.V.Khotylyova [16-17], statistic processing of the results obtained had been realized with the use of the computer programs «Statistik» and «Statistik-6».

Results of investigation. Adaptive potential of the plants - is the ability to adapt to the constantly varying conditions of environment and to form the sustainable high productivity. During the five years of the conducted researches there were made such conditions that allowed defining this potential in the plants of lovage and motherwort. Forming the full-value commodity raw material of lovage (rosette shaped leaves) takes place during 25-30- days, formation of the generative organs (flower spike, inflorescence) starts on the 52-57day. Mass blooming of lovage plants (raw material during the blossoming - for processing) takes place during 66-71 days. At the end of the blooming stage the plants have the already formed 3-4 - central stems-flower spikes, each of which ends with a central umbel 19-34- side ones. In the process of blooming big rosette shaped leaves consequently die out and those, which are formed near the stem - are considerably smaller. The height of the bush together with the flower spike is about $120-180 \mathrm{~cm}$ and higher. After the pollination, the process of forming the seeds takes place 45-48 days, after that the seed gains its characteristic coloring. The period of development of the lovage plant from the sprouts (during the next years - growing) to the full seeds ripening lasts in average for 116-121 days.

Formation of productive medicinal raw material (flowering apical shoots) of motherwort lasts during 6075 days. The blooming of the plants begins on the 50-60th day of the shoots and lasts for 25-30 days. At the beginning of blossoming, the plants have the alredy formed stems and branches of the first and second order, and branches of the third and subsequent orders are being formed less often. By the end of flowering the branches of the third order are formed. The height of the bush reaches $75-120 \mathrm{~cm}$. After pollination, the seed formation process takes place within 46-52 days, after which the formed and mature seeds acquire the characteristic coloring of the species. The period from the shoots to the full seeds ripening of motherwort lasts for $140-145$ days (table 1 ).

Table 1 - Duration of Forming the Commodity Raw Material and Yield capacity of the Collection Samples (in average during 2011-2016 years)

\begin{tabular}{|c|c|c|c|c|c|}
\hline \multirow[t]{3}{*}{ Samples } & \multicolumn{2}{|c|}{ Vegetation duration, days to } & \multirow{3}{*}{$\begin{array}{l}\text { Violation from the } \\
\text { standard } \pm\end{array}$} & \multicolumn{2}{|c|}{ Yield capacity } \\
\hline & & & & \multirow{2}{*}{$\begin{array}{c}\text { Green mass, } \\
\text { t/ha }\end{array}$} & \multirow{2}{*}{$\begin{array}{l}\text { Seeds, } \\
\mathrm{kg} / \mathrm{ha}\end{array}$} \\
\hline & $\begin{array}{c}\text { Bush mass / } \\
\text { Beginning of } \\
\text { blooming. }\end{array}$ & \begin{tabular}{|l|} 
Seeds \\
ripening
\end{tabular} & & & \\
\hline \multicolumn{6}{|c|}{ Lovage medicinal } \\
\hline Mriya (St) & 37 & 120 & - & 17,2 & 710 \\
\hline Lovedge & 38 & 118 & -2 & 22,9 & 770 \\
\hline MLL & 37 & 116 & -4 & 28,3 & 768 \\
\hline Redei & 38 & 113 & -7 & 27,3 & 919 \\
\hline K-3 & 40 & 117 & -3 & 20,4 & 732 \\
\hline KJ & 30 & 107 & -8 & 23,1 & 800 \\
\hline Coral & 36 & 116 & -4 & 28,0 & 874 \\
\hline $\mathrm{HIP}_{05}$ & 1,5 & 1,4 & - & 1,3 & 24,5 \\
\hline \multicolumn{6}{|c|}{ Motherwort five-lobed } \\
\hline CRBS (St) & 60 & 109 & - & 6,4 & 164 \\
\hline SK-1 & 51 & 100 & -9 & 7,0 & 188 \\
\hline SK-2 & 53 & 101 & -8 & 8,6 & 184 \\
\hline Zabava & 58 & 107 & -2 & 7,9 & 188 \\
\hline Krasunya & 54 & 105 & -4 & 8,6 & 192 \\
\hline
\end{tabular}




\begin{tabular}{|l|l|l|l|l|l|}
\hline $\mathrm{HIP}_{05}$ & 2,5 & 1,2 & - & 1,0 & 19 \\
\hline
\end{tabular}

According to the assessment of the lovage source material there had been singled out the samples that were characterized by a short period of forming the commodity raw material - MLL (37days, yield capacity 28,3 t/ha of green mass), sort Coral (correspondingly 36 days and 28,0 t/ha) and the sort of the foreign collection Redei (38 days and 27,3 t/ha).

A short period of the motherwort plants development and a high productivity of the green is a characteristic feature of the samples SK-2 (53 days and 8,6 t/ha of the green mass), new sort Krasunya (correspondingly 54 days and 8,6 t/ha). The shortest period of commodity raw materials forming has got the sample SK-1 - 51 day, but it was inferior to the yield $-7,0$ t/ha.

An important indicator of adaptive ability is productivity of plants in clearly defined agro-climatic conditions. Therefore, to obtain the high-quality crops of aromatic medicinal plant material, it is necessary to develop a model of the variety, which would include the following important characteristics: the energy potential of the cultivation zone, a detailed description of valuable breeding features that affect the productivity and yield of quality raw materials, and resistance to unfavorable environmental factors. The sign of productivity is a complex feature, which depends on a number of components, and to fully realize it, it is necessary to identify the maximum number of characteristic features that form this feature. Therefore, we have investigated the correlation between the selection criteria of the samples of lovage and motherwort.

In accordance with the correlative connections between the valuable selection characteristics of lovage, four groups had been singled out, which differ in the level of cooperation, being the high correlative dependences that were noticed between the length of the stem and the leaf width $(r=0.71)$, umbel diameter $(r=$ 0.85 ) and amount of the central inflorescences ( $r=0.66)$; leaf width and umbel diameter ( $r=0.71)$; essential negative connection is observed between the green mass from the plant $(r=-0.84)$, green mass crop productivity $(r=-0.84)$ and the amount of stems on the bush, and as well between the amount of the central inflorescences and bush diameter $(r=-0.66)$. There had been noticed the average positive connection between the diameter of the bush and the mass from the plant $(r=0,59)$ and yield capacity of the green mass $(r=0.58)$, between the length of the leaf and the bush diameter $(r=0.46)$, between the leaf width and the height of the bush ( $r=0.54)$. A low correlative connection had been observed between the length of the leaf and the amount of the stems on the bush. $(r=0.39)$.

Consequently, we have established that the formation of the lovage productivity is taking place, depending on the formation of quantitative and qualitative characteristics, as well as on the influence of factors of climatic conditions. Table 2 shows the characteristics of the samples based on the characteristics that form the productivity and yield of plants.

Table 2 - Assessment of the Lovage Samples Potential (average during 2011-2016)

\begin{tabular}{|c|c|c|c|c|c|c|c|}
\hline \multirow[t]{2}{*}{ Basic characteristics } & \multicolumn{7}{|c|}{ Samples } \\
\hline & Mriya St & Lovedge & Redei & MLL & $\mathrm{K}-3$ & KJ & Coral \\
\hline 1 & 2 & 3 & 4 & 5 & 6 & 7 & 8 \\
\hline $\begin{array}{l}\text { Duration of the plant's } \\
\text { development, days (to the phase } \\
\text { of mass blooming) }\end{array}$ & 37 & 38 & 38 & 37 & 40 & 30 & 36 \\
\hline Height of the bush, $\mathrm{cm}$ & 60,0 & 70,9 & 68,0 & 73,3 & 69,0 & 68,0 & 72,0 \\
\hline Diameter of the bush, $\mathrm{cm}$ & 39,4 & 53,9 & 55,7 & 55,1 & 56,0 & 60,0 & 46,0 \\
\hline Yieid productivity & & & & & & & \\
\hline Above ground mass, $\mathrm{t} / \mathrm{ha}$ & 17,2 & 22,9 & 27,3 & 28,3 & 20,4 & 23,1 & 28,0 \\
\hline Seeds, kg/ha & 210 & 770 & 768 & 919 & 732 & 800 & 874 \\
\hline Mass of 1000 seeds & 1,23 & 1,20 & 1,56 & 2,60 & 1,90 & 2,0 & 2,62 \\
\hline
\end{tabular}




\begin{tabular}{|l|l|l|l|l|l|l|l|}
\hline \multicolumn{1}{|c|}{ Content: } & & & & & & & \\
\hline Dry matter, \% & 17,2 & 19,3 & 19,8 & 20,2 & 16,2 & 23,0 & 20,4 \\
\hline Ascorbic acid, mg/100 g & 22,0 & 16,3 & 21,2 & 32,3 & 25,6 & 26,0 & 32,5 \\
\hline Essential oil, \% on the raw mass & 0,16 & 0,19 & 0,20 & 0,28 & 0,20 & 0,22 & 0,28 \\
\hline
\end{tabular}

Analysis of the medicinal lovage source material had shown that the samples of the home selection are on a par with the foreign analogs. Sample MLL and a new sort Coral were characterized by a high indicator of the valuable selection features and a high content of the useful materials. The sorts of the foreign selection Lovedge and Redei were resistant to the conditions of growing in the lowland zone of Transcarpathia: the height of the plant was 70,9 and $68,0 \mathrm{~cm}$, diameter of the bush correspondingly 53,9 and $55,7 \mathrm{~cm}$, green mass productivity made up 22,9 and $27,3 \mathrm{t} / \mathrm{ha}$, commodity raw material output was on the level of $54,3-56,7 \%$. The study of correlative dependence of the motherwort five-lobed samples had shown, that the tightest it was between the amount of stems on the ( $r=0.89)$, amount of branches of the 1-st order and bush diameter $(r=0.96)$, between the amount of branches of the 1-st order $(r=0.84)$, amount of the inflorescences and amount of the stalks on the bush $(r=0.88)$, mass from the plant and yield capacity and the amount of inflorescences on the plant $(r=0.72$ and 0,70 ). The average dependence was between the mass per plant, green mass crop and bush diameter, stems amount and 1-st order branches amount. The range of fluctuation of the coefficient of correlation made up $0,60-0,67$, which points on the possibility of selection, on the combining of these features.

In the table 3 the characteristics of the motherwort samples according to the productivity and quality of the plant raw material are shown.

Table 3 - Analysis of the Motherwort Five-lobed Samples (in average during 2011-2016)

\begin{tabular}{|l|c|c|c|c|c|}
\hline \multirow{2}{*}{ Basic indicators } & \multicolumn{5}{c|}{ Samples } \\
\cline { 2 - 6 } & CRBS & SK-1 & SK-2 & Zabava(St) & Krasunya \\
\hline \multicolumn{1}{|c|}{1} & 2 & 3 & 4 & 5 & 6 \\
\hline Duration of vegetation period, days & 123 & 127 & 129 & 127 & 118 \\
\hline Height of the bush, cm & 132,0 & 129,7 & 136,7 & 132,3 & 127,0 \\
\hline Bush diameter, cm & 41,0 & 46,2 & 45,6 & 47,1 & 53,1 \\
\hline \multicolumn{1}{|c|}{ Productivity : } & & & & & 7,9 \\
\hline Green mass, t/ha & 6,4 & 7,0 & 8,6 & 185 & 192 \\
\hline Seeds, kg/ha & 164 & 188 & 184 & & \\
\hline Content : & & & & 28,0 & 29,2 \\
\hline Dry matter, \% & 24,5 & 27,4 & 29,4 & 0,20 & 0,22 \\
\hline Leonurine, \% & 0,19 & 0,20 & 0,22 & 0,70 & 0,66 \\
\hline Flavonoid sum, \% & & & 0,66 & 0,05 & 0,05 \\
\hline Essential oil, \% on green mass & 0,03 & 0,04 & 0,05 & 1,0 & 1,1 \\
\hline Mass of 1000 seeds & 0,8 & 1,0 & 1,1 & & \\
\hline
\end{tabular}

During the period of investigation, the samples were defined that can serve the sources of the valuable characteristics, being: according to the short vegetation period (Krasunya, CRBS), bush height (SK-2, Zabava, CRBS), according to the bush diameter (Krasunya, Zabava, SK-1), content of useful substances (Zabava, SK-2 and Krasunya), in amount of stems per bush (SK-1, SK-2), in the amount of the branches of the 1-st and 2-nd order (Zabava, SK-2) and the amount of inflorescences on the bush (SK-1, SK-2).

When growing the aromatic and medicinal plants, the high economic effect provides the output of the commodity qualitative plant raw materials, as according to these characteristics, its realization takes place. 
Lovage and motherwort commodity raw materials are their over ground mass. That's why the ability of the plant to grow the maximum of this mass shows the potential of these types' productivity.

The results obtained from the source material show that in the same climate zone during the period of 2011-2016 years, the sorts considerably varied in productivity, range of fluctuation of which was on the level from $1,4\left(14,0 \mathrm{t} / \mathrm{ha}\right.$ ) to $2,8 \mathrm{~kg} / \mathrm{m}^{2}$ (28 t/ha) - in lovage and from $0,46(4,0 \mathrm{t} / \mathrm{ha})$ to $0,86 \mathrm{~kg} / \mathrm{m}^{2}(8,6 \mathrm{t} / \mathrm{ha})-$ in motherwort. In the lowland zone of Transcarpathia the perspective ones for the selection are the samples of lovage with the plants' mass not less than $200-324 \mathrm{~g}$ and the output of the commodity raw material $-50-56 \%$, and motherwort - not less than 100-120 g and 49-54\% correspondingly. According to the given indicators, there had been singled out the following samples : Lovage - MLL $-423,2 \mathrm{~g}$ and $56,0 \%$ (green mass yield 28,3 t/ha), Redei $-407,2 \mathrm{~g}$ and 52,8 \% (green mass yield 27,3 t/ha), Coral $-385,0$ and 51,1 \% (green mass yield 28,0 $\mathrm{t} / \mathrm{ha}$ ); motherwort - SK-2 - 214,7 g and 52,5\% (green mass yield 6,1 t/ha), Zabava - 198,3 g and 49,6\% (correspondingly 5,7 t/ha) and Krasunya $-174,4 \mathrm{~g}$ and 50,2\% (8,6 t/ha correspondingly).

Except for the genetic characteristics of the plant, and agro technological factors, the climate conditions of the vegetation period influenced the level of yield capacity as well. The sum of downfalls during the years 2011-2016 differed from $186 \mathrm{~mm}$ to $317,3 \mathrm{~mm}$, and the sum of active temperatures was on the level of -3211 $3569^{\circ} \mathrm{C}$. The most favorable were the years 2011,2013 and 2016 , the combination of the maximum sum of active temperatures and sum of downfalls. Green mass productivity of lovage plants was within the level of 10,8 (2015)-33,8 t/ha (2013) and of motherwort during the period of 2011-2016 fluctuated within the measures of 3,23 (2014)-12,1 t/ha (2016). Variation coefficient in the sum of active temperatures for both cultures made up $3,88 \%$, in the downfalls $-20,19 \%$, in the combined action of downfalls and temperature the coefficient was $21,31 \%(r=0,77$ - lovage, $r=0,58$-motherwort ), in the productivity - correspondingly in lovage $V=43,1 \%$ (correlation coefficient was on the level of 0,53 ); in motherwort $-V=56,0 \%$ (correlation coefficient made up 0,61 , which confirms the genotype changeability of the yield and influence of the climate conditions.

Valuable index of genetic attractiveness of plants of initial forms is their adaptability. Highly adaptive genotype can significantly reduce the effects of limiting environmental factors, both in a combination of plants of the genotype, and for each plant as well. Knowledge of the laws of environmental variability of the manifestation of various characteristics is very important for the creation of varieties with a high stable indicators of basic economic household characteristics.

The degree of response of genotypes to the changing environment is estimated using the coefficient of environmental plasticity (bi). It reflects the flexibility and stability of the sample relative to the average expression of the reaction of all studied forms to the changing environment during the years of study.

Investigating the adaptability of the samples of the source material of lovage and motherwort during the period of 2014-2016 on the basis of the weight of plants and yield, a rather significant amplitude of the fluctuation of the coefficients of ecological plasticity and variation was found (Table 4).

All the samples of lovage both under the characteristics of the plant's weight and yield are almost identically sensitive to the changes of ecological environmental factors. The amplitude of fluctuation of the coefficient of ecological plasticity $\left(b_{i}\right)$ of these indicators made up from 0,23 to 2,68 . Less sensitive to the changes of growing conditions were the samples Lovedge (0,23 - plant's mass, 0,24 - yield), MLL (correspondingly - 0,31). In the standard variety Mriya and a new Coral sort these indicators were within the level of 0,40 and 0,43 , both in the plant's mass and yield capacity. Variation coefficient $\left(V_{i}\right)$ of the source material according to the mass of plants was within the level from $-27,99$ (Coral) to $+85,81$ (K-3). The negative meaning of this indicator had the following varieties - Lovedge - $-50,95$, MLL $--39,69$, Mriya $--36,12$ and Coral $--27,99$ 


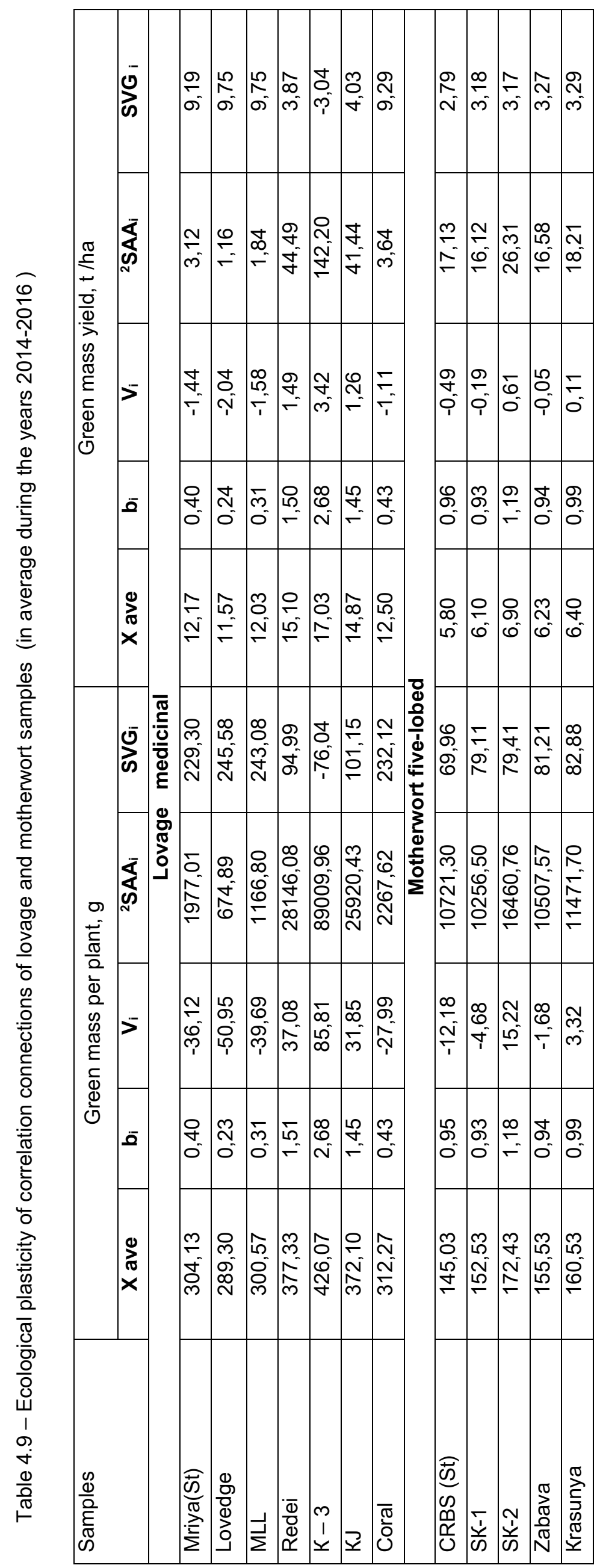


Variability of the mass from the plant, high rates of reaction to separate growing conditions at a high specific adaptive ability showed the following samples $(S A A)$ : K-3 $(S A A=89009)$, Redei $(S A A=28146)$ and $\mathrm{KJ}(\mathrm{SAA}=25920)$. These samples also stood out in the yields - correspondingly 142.2, 44.89 and 41.44 .

Selection value of the genotype (SVG), which reflects the combination of high yield and stability. According to the weight of plants and yield, the indicators of the SVG were high $(245.6,243.1$ and 9.75, 232.1 and 9.29, 229.3 and 9.19 respectively) in the samples of Lovedge, MLL, Coral and Mriya.

The amplitude of the fluctuation of the coefficient of ecological plasticity (bi) of the samples of the motherwort of the mass of the plant and the yield was from 0.93 to 1.19 , respectively. In the samples of CRBS and SC-1, the coefficients of variation had negative values -12.18 and -4.68 - the mass of plants and, correspondingly, -0.49 and -0.19 , the yield of plants. The following samples had a specific adaptive ability, both in weight from the plant, and in yield: SK-2 $(S A Z=16460$ and 26.31) and Krasunya $(S A Z=11471$ and 18.21).

Fluctuation of the parameters of SVG of the motherwort samples were insignificant: in the plant's weight - from 79,11 to 82,88 (the exception was the sample CRBS - 69,96); in the commodity raw material yield - from 2,79 to 3,29. However, we can single out the samples Zabava and Krasunya. These samples had the highest indicators.

\section{Conclusions}

The study of the samples of genetic fund of Levisticum officinalis Koch. And Leonurus guinguelobatus Gilib in the conditions of Transcarpathia had shown, that these cultures are perspective ones for growing in the lowland zone of Transcarpathia. Their perspective is conditioned by: 1) a wide specter of use in different branches of production; 2) unpretentiousness to the growing conditions and ability to grow on the soils, not suitable for growing other valuable basic agricultural crops; 3 ) filling the market of the given region with their own medicinal raw materials.

The conducted analysis of the investigations according to the valuable selection features and study of the adaptive ability of the samples allowed to more precisely choose the parental pairs for the strengthening of the characteristics of adaptive ability and yield capacity and involve them into the selection process. Due to the results of investigations, we had singled out the samples that show a high adaptive ability to the conditions of growing and can serve the sources for the creation of adaptive varieties of lovage and motherwort.

\section{Bibliography}

1. Smuk G.K. (1990). U prurodi i na ogorodi. [In nature and in the garden ]. Kyiv: Yield. P. 119-120. [in Ukraine].

2. Korablyova O.A. (2011) Pryanosti i pripravu [Spices and seasonings]. Kyiv: Yunivest Media. 196 p. [in Ukraine].

3. Kormosh S.M. (2012) Ocinka kolekcinuh zrazkiv ta osnovni napriamku formuvannia vuhidnoho materialu liubustku likarskoho - dgjerel cinnuch oznak dlia selekcii v umovach nuzunnoi zonu Zakarpattia. [Assessment of collection samples and basic directions of forming the initial source material of lovage - the sources of valuable characteristics for selection in the conditions of lowland zone of Transcarpathia ]. Genetic resyrse of plant. No.10-11. P. 123-131. [in Ukraine].

4. Sinelynikov S., Solomonnik T. (2005). Specii, pripravu I pryanosti.Preday ghizni vkus. [Seasonings and spices. Give taste to life ]. Kyiv: Zao Centrpolygraf, P. 32, 142, 208. [in Ukraine].

5. Grodzinskiy A.M. (1992) Lykarscy roslunu: encuklopeduchnuy dovidnuk [Medicinal plants: Encyclopedic reference book] Kyiv: Vydavnuctvo "Ukrayinska enciklopediya" im. M.P. Badgana, 1992. P. 405-406. [in Ukraine].

6. Horova T.K. (1999) Znachennya integrovanoi prirodu adaptuvnoho potencialy selekcii koreneplidnuh I zelenuh roslun. Optumizaciya selekciynoho procesy na osnovi henetuchnuh metodiv: materialu mignarodnoi naykovo] conferencii [Significance of integral nature of adaptive potential in the selection of root vegetable 
and green plants. Optimization of the selection process on the basis of genetic methods: materials of international scientific conference (Kharkiv, Ausust, 18-20,1999)]. Kharkiv, 1999. P. 59-60. [in Ukraine].

7. Khareba V. V. (2004) Naykovi osnovu vurobnuctva kapustu biloholovoi v Ukraini [Scientific bases of white cabbage production in Ukraine]. Kharkiv, IOB, UAAS, 2004. P. 27-29. [in Ukraine].

8. Pivovarov V.F., Dobrutskaya Y.G., Balashyova N.N. (1994) Ecologicheskaya selekciya selkohozyaystvennuh rasteniy [Ecological selection of agrarian plants]. M, 1994. 248 p. [in Russia].

9. Zhuchenko A.A. (1980) Ecolohicheskaya henetica kulturnuh rasteniy [Ecological genetics of cultural crops]. Kyshinyov: Shtiintza, 1980. 585 p. [in Moldova].

10. Litun P.P. (1980) Vzaimodeystviye henotip-sreda $v$ heneticheskih I selekcionnuh issledovaniyah I sposobu eho izucheniya / Problemu otbora I selekcionnoho materiala [Cooperation genetic type environment in the genetic and selection researches and the ways of its study. Problems of selection and selection material] Kyiv: Scient. Thought, 1980. P. 63-92. [in Ukraine ].

11. Arinshteyn A.P. (Eds). (1997) Selekciya efiromaslichnuh kyltur. Metodicheskie ykazaniya. [Selection of essential oils cultures. Methods restrictions]. Simferopol. P. 100-108. [in Krym].

12. Karpatchova A.N. (Eds). (1972). Biohimicheskiye metodu analiza efiromaslichnuh rasteniy I efirnuh masel. [Biochemical methods of analysis mof essential oils plants and essential oils: coll. Sc.works]: sbornic nauchnih trudov. Simferopol. 107 p. [in Ukraine].

13. Issikov V.P., Rabotyagov V.D., Hlupenko L.A. (2009) Introdukciya I selekciya aromaticheskih I lekarstvennuh rasteniy. Metodolohicheskiye I metodicheskiye aspecti. [Introduction and selection of иaromatic and medicinal plants. Methodological and methods aspects] Yalta: Nicitskiy botanicheskiy sad. 110 p. [in Ukraine].

14. Kormosh S.M., Leonova O.M. (2007) Metodica provedennya ekspertizi sortiv lyubistku licarskoho (Levisticum officinalis C. Koch.) na vidminnist, odnoridnist I stabilnist. [Methods of conducting the expert assessment of the varieties of lovage (Levisticum officinalis C. Koch.) on the difference, homogeneity and sustainability] Ohorona prav na sorty roslun. Oficiyniy byuleten, metodiki. [Protection of rights on the plants' varieties. Official bulletin, Methodics]. Part. 3, No 2. P. 167-176. [in Ukraine ].

15. Kormosh S.M. (2011) Metodica provedennya ekspertizy sortiv sobachoyi kropyvy pyatilopatevoyi (Leonurus guinguelobatus Gilib) na vidminnist, odnoridnist I stabilnist. [Methods of conducting the expert assessment of the varieties of motherwort (Levisticum officinalis C. Koch.) on the difference, homogeneity and sustainability. Protection of rights on the plants varieties] Ohorona prav na sorty roslun. Oficiyniy byuleten, metodiki. [Official bulletin, Methodics]. Part. 3, No 2. P. 1-8. [in Ukraine].

16. Kilchevskiy A.V., Khotylyova L.V. Metod ocenki adaptivnoy sposobnosti I stabilnosti henotipov, differenciruyushchey sposobnosti sredu. Soobshcheniye. Obosnovanie metodov [Method of assessment of the adaptive ability and stability of the genotypes, differentiating the abilities of the environment. Report 1. Methods grounding]. [Genetics]. 1985. V.21, № 9. P. 1481-1490. [in Russia].

17. Kilchevskiy A.V., Khotylyova L.V. Ocenka adaptivnoy sposobnosti I stabilnosti sortov I hibridov ovoshchnuh kultur [Assessment of adaptive ability and stability of the varieties and hybrids of the vegetable cultures]. Metodicheskiye ukazaniya po ecolohicheskomy isputaniyu ovoshchnuh kultur $v$ otkrutom grunte. [Guidelines on the ecological crosses of the vegetable cultures in the open soil]. M. 1985. P.2. P. 43-53. [in Russia]. 